\title{
四国地方の地殼構造
}

高知大学理学部高知地震観測所木 村 昌 三

(昭和 54 年 7 月 2 日受理)

\section{Upper Crustal Structure in the Shikoku District}

\author{
Shozo KIMURA \\ Kochi Earthquake Observatory, Faculty of Science, Kochi University
}

(Received July 2, 1978)

It is pointed out that the focal distribution in central and eastern Shikoku obtained on the assumption of a structure model of four horizontal layers shows some remarkable characteristics. For example, the uppermost boundary of focal distribution of shallow earthquakes inclines downwards to the south in the Chichibu and Shimanto Belts and is very shallow in the Sanbagawa B. Therefore, in order to investigate the crustal structure in relation to such distributions of earthqakes, seismic waves generated by quarry blasts on Mt. Torigatayama, Kochi Pref. were observed at 48 temporary stations along 4 profiles of the E, $\mathrm{NE}, \mathrm{N}$ and $\mathrm{S}$ directions. Apparent velocities are considerably different for directions of the profiles. This difference is elucidated by inclination of the crustal layers. From the travel time curves obtained, the following crustal structure model was inferred.

P-wave velocities are estimated at $4.8,5.5$ and $6.1 \mathrm{~km} / \mathrm{sec}$ for three layers, respectively. Trend directions are calculated at $\mathrm{E} 21-25^{\circ} \mathrm{N}$ for these layers. This direction coincides nearly with the tectonic axis of the Shikoku Island and the direction of the Mikabu Tectonic Line in central Shikoku. The first layer with the velocity of $4.8 \mathrm{~km} / \mathrm{sec}$ exists only in the southern region of the Mikabu T.L. and its thickness changes southwards from 0.6 to $3 \mathrm{~km}$. The lower interface of the second layer with the velocity of $5.5 \mathrm{~km} / \mathrm{sec}$ decends southwards with steep gradient and its thickness changes from 4 to $12 \mathrm{~km}$. This gradient of the upper interface of the $6.1 \mathrm{~km} / \mathrm{sec}$ layer is in harmony with the uppermost distribution of focal depths of shallow earthquakes. Small thickness of the $5.5 \mathrm{~km} / \mathrm{sec}$ layer in the Sanbagawa Metamorphic Belt compared with its surrounding regions may suggest the upheaval of the Belt by recent tectonic activities.

\section{§1. はじめに}

四国地方に発生する浅い地震には顕 著な特徵が見られる.Fig.1は岡野・ 他（1977）によつて求められたもので, 1975 年から 1976 年の 2 年間にわた つて高知と徳島の両観測所で観測され た地震の震源を南北の断面に投影した

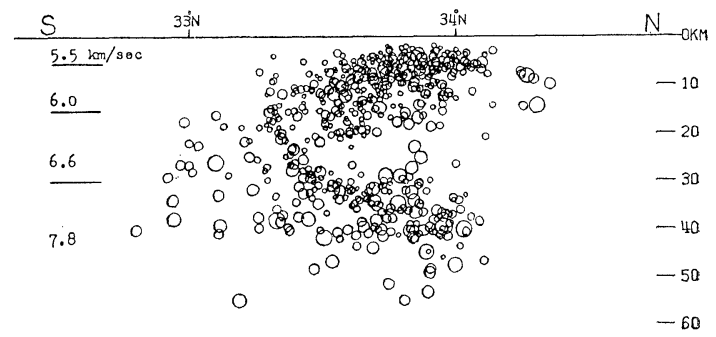

Fig. 1. Focal depth distribution in a vertical section $(\mathrm{N}-\mathrm{S})$ with the assumed crustal structure (after K. OKano et al. (1977)). 
ものである，同図の左側には震源決定の際に用いた水平層構造モデルを併せて示している，浅 い地震の深さの上限は南下がりに分布し，御荷鉾構造線より北になると震源の深さは非常に浅 くなり，三波川帯中部から北側に発生する浅いと思われる地震の震源は求まりにくい。このよ うに系統的に震源の深さ分布に影響をおよぼしている原因としては，用いられた層構造が実際 の地殼上部の構造とは異なり，局所的なあるいは広域の地質帯にまたがるような構造の相違が 考えられる。

一方，爆破地震動観測により四国地方の地殼構造を求めた研究としては，例えば [市川 (1968)，青木・村松(1974)] があり，主に四国北部の構造が得られている．しかしながら，観 測網下の地殼上層部の構造に関しては不明であるため，これを解明する目的で採石発破の波を 観測した。

\section{$\S 2$. 観 測}

この地方の採石発破は数多いが，遠方までの初動の到達が考学られる鳥形山の石灰岩の採石

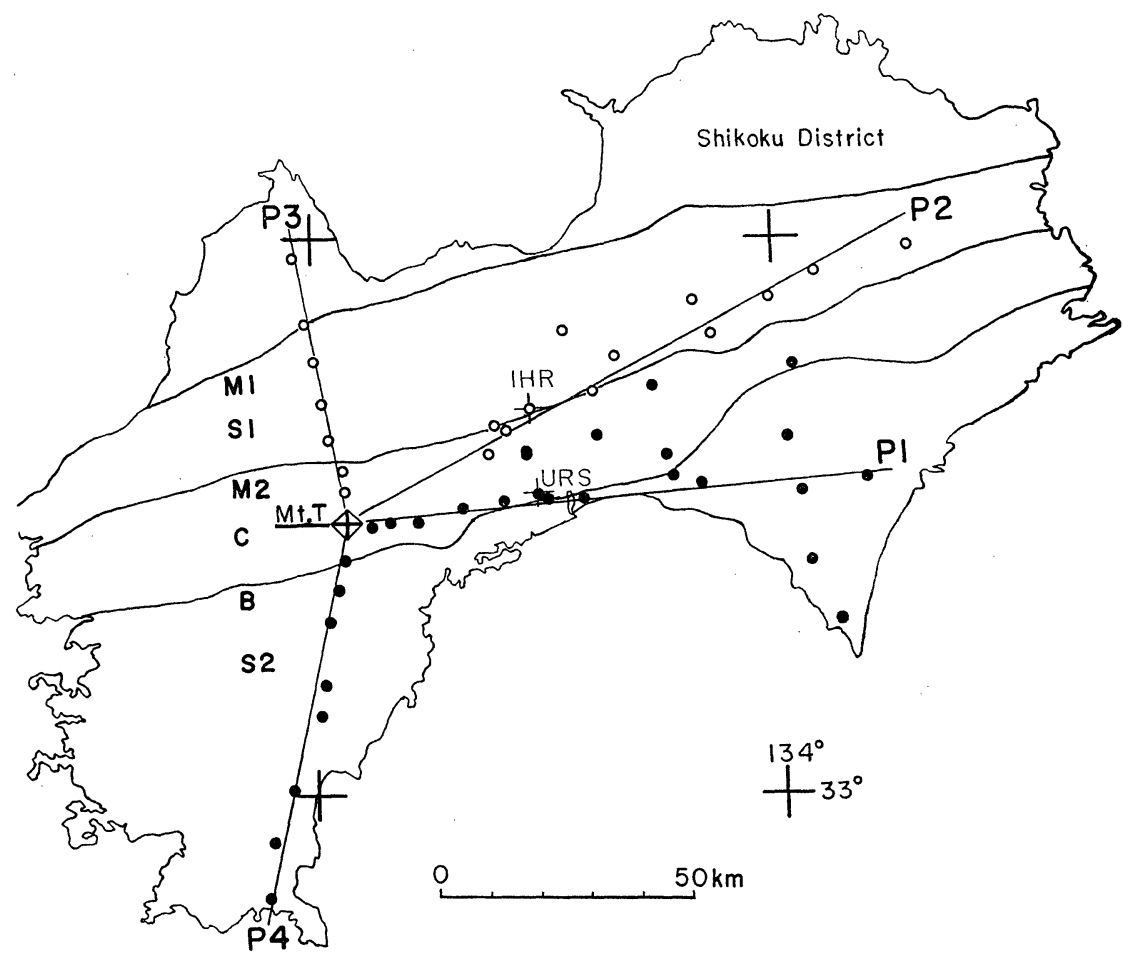

Fig. 2. Locations of Mt. Torigatayama and observation stations. Solid and open circles indicate temporary stations for profiles $\mathrm{P} 1, \mathrm{P} 4$ and $\mathrm{P} 2, \mathrm{P} 3$, respectively. M1: Median Tectonic Line, S1: Sanbagawa Belt, M 2: Mikabu T. L., C: Chichibu B., B: Butsuzo T. L., S 2: Shimanto B. 


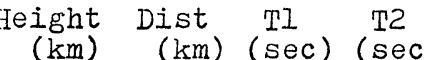

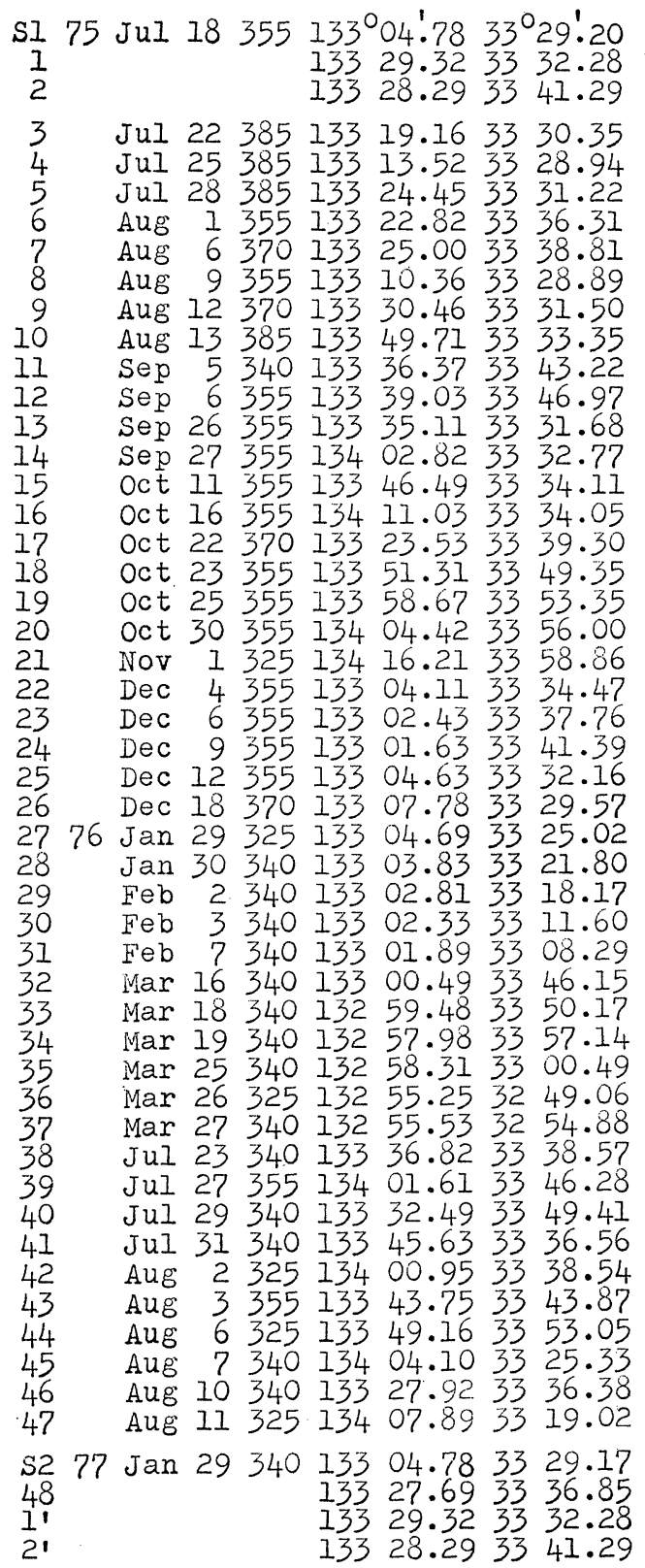

1.355

$\begin{array}{lll}0.02 & 38.46 \quad 7.46\end{array}$

$\begin{array}{lll}0.51 & 42.79 & 7.81\end{array}$

$\begin{array}{lll}0.08 & 23.03 & 4.57\end{array}$

$0.20 \quad 14.15 \quad 3.03$

$\begin{array}{lll}0.05 & 31.35 & 6.09\end{array}$

$\begin{array}{lll}0.31 & 30.99 & 6.05\end{array}$

$\begin{array}{lll}0.56 & 36.42 & 6.88\end{array}$

$\begin{array}{lll}0.30 & 8.69 & 1.90\end{array}$

$\begin{array}{lll}0.18 & 40.33 & 7.79\end{array}$

$0.26 \quad 70.66 \quad 13.05$

$\begin{array}{lll}0.54 & 55.20 \quad 9.85\end{array}$

$0.29 \quad 62.4710 .97$

$\begin{array}{lll}0.03 & 47.26 & 8.99\end{array}$

$0.3290 .18 \quad 16.3916 .94$

$0.07 \quad 65.3012 .10$

$0.47 \quad 103.03 \quad 18.65$

$\begin{array}{lll}0.26 & 34.67 & 6.47\end{array}$

$0.92 \quad 81.17 \quad 14.10$

$0.72 \quad 94.6516 .28$

$0.47 \quad 104.77 \quad 18.02$

$0.58 \quad 123.1121 .04$

$0.70 \quad 10.08 \quad 2.05$

$\begin{array}{lll}0.54 & 16.52 & 3.23\end{array}$

$\begin{array}{lll}0.60 & 23.33 & 4.45\end{array}$

$0.20 \quad 5.77 \quad 1.16$

$0.34 \quad 5.13 \quad 1.07$

$0.46 \quad 7.56 \quad 1.66$

$\begin{array}{lll}0.54 & 13.56 & 2.88\end{array}$

$\begin{array}{lll}0.39 & 20.42 & 4.21\end{array}$

$\begin{array}{lll}0.23 & 32.56 & 6.50\end{array}$

$\begin{array}{lll}0.26 & 38.71 & 7.55\end{array}$

$0.57 \quad 32.28 \quad 6.17$

$0.18 \quad 39.88 \quad 7.36$

$\begin{array}{lll}0.39 & 52.97 \quad 9.68\end{array}$

$0.10 \quad 53.8010 .22$

$0.09 \quad 75.5414 .07 \quad 14.28$

$0.08 \quad 64.8512 .1312 .36$

$\begin{array}{llll}0.22 & 52.49 & 9.75 & 9.92\end{array}$

$0.60 \quad 93.68 \quad 16.48$

$0.59 \quad 57.4010 .17$

$0.21 \quad 64.6111 .8712 .10$

$0.29 \quad 88.44 \quad 15.93 \quad 16.47$

$0.59 \quad 66.4211 .94$

$0.38 \quad 81.43 \quad 14.12$

$0.19 \quad 92.06 \quad 16.86 \quad 17.25$

$\begin{array}{lll}0.17 & 38.18 & 7.11\end{array}$

$\begin{array}{llll}0.07 & 99.4018 .24 & 18.76\end{array}$

1.340

$\begin{array}{lll}0.13 & 38.25 & 7.11\end{array}$

$0.02 \quad 38.47 \quad 7.45$

$0.51 \quad 42.81 \quad 7.79$

Table 1. Coordinates and levels of shot points and observation stations, shot distances and travel times. $\mathrm{T} 1$ is the time for first arrivals and $\mathrm{T} 2$ for later phases. $\mathrm{BN}$ indicates levels of shot points reduced by $1000 \mathrm{~m}$. 
発破を利用した。広域の細かな地殼上層部の構造を求めるため, 観測点を密にしかも広い範囲 にわたつて設けた，発破点の鳥形山执よび観測点の位直をFig. 2 に示し，十印の点は鵜来巣， 石原の常時観測点である. 測線 P $1, \mathrm{P} 4$ 亿対応する観測点を黒丸で, 測線 P $2, \mathrm{P} 3$ 亿対応す る観測点を白丸で示す．観測点の経度，緯度， P 波の走時等を Table 1 に示している.

地震計は発破点では $4.5 \mathrm{cps}$, 移動観測点では $1 \mathrm{cps}$ の固有振動数のものを用いた。記録は 1975 年 8 月 1 日までは物探用の光学記録計を約 $10 \mathrm{~mm} / \mathrm{sec}$ のスピードで流してとり, これ 以後はデータレコーダ (ソニー製, FRC-1402D) でとり，再生は $50 \mathrm{~mm} / \mathrm{sec}$ のスピードの ペンレコーダで行なつた.

鳥形山山頂での発破観測は 1975 年 7 月 10 日, 同年 7 月 18 日, 1977 年 1 月 29 日の 3 回であり, そのときの発破点の位直 は各々 Fig. 3 の S 0, S 1, S 2 である. 採石方法は Fig. 3 のベンチナンバー (図中太字) に見られるように，高さ $15 \mathrm{~m}$ の階段状に採石してゆく露天掘 りである。観測時の薬量は 1 回目より $3,4,2.2$ トンであつた. 1 つのホー ルの薬量は 0.15 トンなので 1 回分の

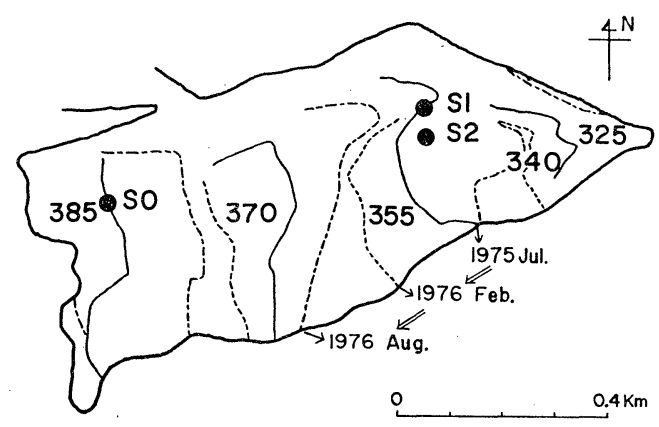

Fig. 3. Map showing a quarry on Mt. Torigatayama. 発破のホール数は多い訳だが，点火は斉発である。観測例として Fig. 4a に 1975 年 7 月 18 日の記録を示す． 3 回の観測で単純な見掛け速度を求めると，各々 $1.2,2.9,3.3 \mathrm{~km} / \mathrm{sec}$ とな つた，石灰岩の弾性波速度は大久保・他（1966）を参考にすると，中・古生層の場合 $4.8 \sim$ $6.0 \mathrm{~km} / \mathrm{sec}$ となつているが，今回の值は非常に小さい。その原因としては，発破による破填 や振動のため石灰岩中に割れ目が増加して岩がガサガサになつたため, 見掛け速度が非常に小

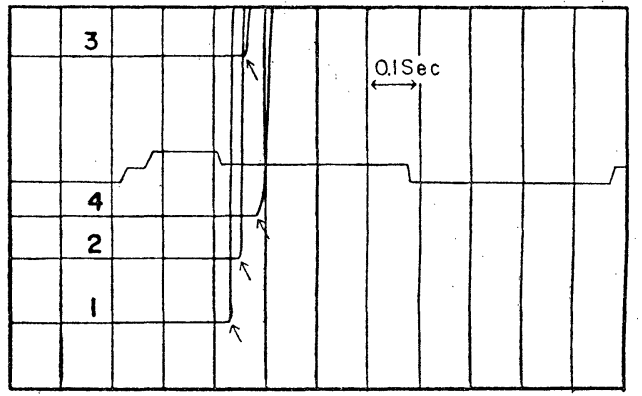

Fig. 4a. Seismogram observed at the shot point on Jul. 18, 1975.
No.1 Ugurusu

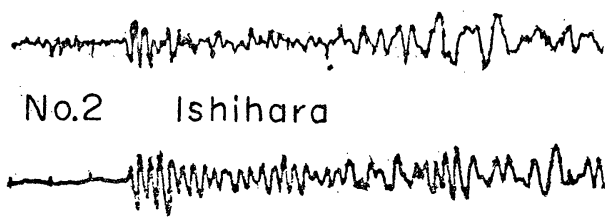

Fig. 4b. Seismograms observed at Ugurusu and Ishihara stations on Jul. 18, 1975. Shot times are estimated from the first arrival times at these stations. 
さく出たものと推定される．解析に際して用いたのは 2 回目の発破のデータであり，ホールに 一番近いピックまでの距離が $26.3 \mathrm{~m}$ なので 0.01 秒の補正を行なつて発破時刻とした.

測線に沿つての観測では，1 点ずつ移動して行ならといら方法をとつたため, 観測毎の発破 時刻を押さえる必要が生じた. このため, 初動の比較的明瞭な鵜来巣, 石原の常時観測点に和 ける初動時刻より, 2 回目の発破で求めた 2 点への所要時間を差し引いて, 移動観測を行なつ た際の発破時刻とした. Fig. $4 \mathrm{~b}$ に Fig. $4 \mathrm{a}$ と同じ日時の鵜来巣，石原の各観測点での波形 を示す．観測当初は Fig. 2 の測線に沿つて主に露岩上にピックを置いて観測を行なつた訳で あるが，測線 P1 と P 2 の間では走時が大きくずれるため，2 つの測線の周囲でより多くの 観測を行なつた。

\section{§1. 解 析}

Fig. 3 に示したように採石場の面積は広く，かつ発破点が日時と共に移動してゆくため， 観測日の大発破（約 1.5 4 トン）のベンチナンバーを控えて扣き，採石進行状況を示す図面 (1/2000) 飞よつて平均の場所を求め, 鵜来巣および石原の初動時刻から求めた発破時刻に発破 点の移動に伴なう補正を加えた。採石場の形や発破時刻を求める方法から考えて, 測線 $\mathrm{P} 1$, $\mathrm{P} 2$ 方向についての䛊差は小さいが，P 3, P 4 方向については大きく， \pm 0.03 秒程度と見込 まれる.一方，発破点の鳥形山の標高は $1.385 \sim 1.325 \mathrm{~km}$ と高く，移動観測点の高さは一定 しないため，それぞれについて高度補正を行なつた。方法は以下に述べる速度の組み合わせを 水平構造に適応させて行ない, 発破点下では 0.14 秒, 観測点では $0.0 \sim 0.07$ 秒を元の走時か

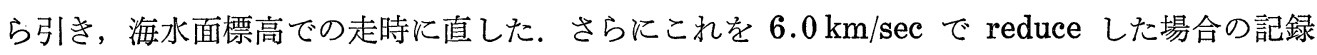
をFigs. 5a, 5b に，走時曲線を Figs. $6 \mathrm{a}, 6 \mathrm{~b}$ に示す. Figs. $6 \mathrm{a}, 6 \mathrm{~b}$ では，初動のあま り明瞭でないもの (横棒)，後続波の読み取れたもの（三角印）扣よび発破点による誤差（綎棒） も併せて示している.

今回は逆測線がないため，観測值から速度を推定した．第 II 層の速度はかなりバラつくが， 各測線に沿う点の初動および後続波の走時を考慮すると $5.5 \mathrm{~km} / \mathrm{sec}$ とみなせる. 次に第 I 層

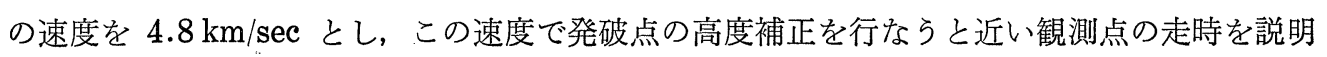
できる、第 III 層の速度は各測線で大きく異なり, 特に $\mathrm{P} 1$ と $\mathrm{P} 2$ でははなはだしい. $\mathrm{P} 1$ のうち, 直線上に並んだ点の間の見掛け速度は $5.8 \mathrm{~km} / \mathrm{sec}$ となり, 上層の影響を取り除いて も小さすぎる.P2 に沿つては勾配が比較的安定しているため, 石原常設点と初動の明膫な観 測点との見掛け速度を求めると $6.0 \sim 6.2 \mathrm{~km} / \mathrm{sec}$ となり, 平均の速度として $6.1 \mathrm{~km} / \mathrm{sec}$ と する. 


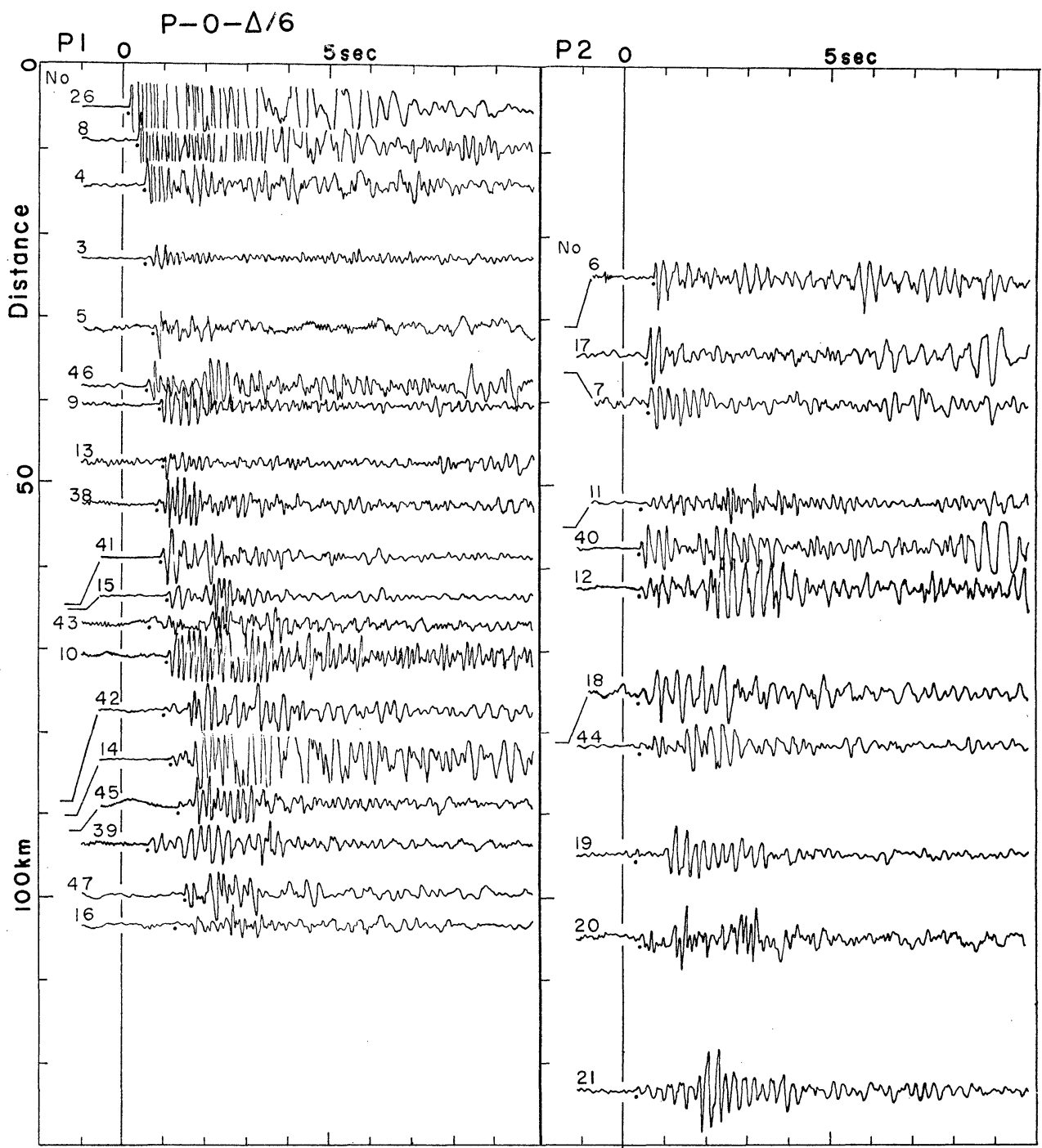

Fig. 5a. Seismograms arranged with reduced travel times and shot distances for profiles P1 and P 2. Initial phases are indicated by dots.

Figs. $6 \mathrm{a}, 6 \mathrm{~b}$ に示された測線によつて変化する走時曲線を説明するには，層の厚さや構成 岩石の相違叔よび弾性波速度の異方性等が考えられる。しかし，観測点の位置と走時との関係 をみると，走時が南から北向つて系統的に早くなつていることから，地質帯構成岩石の速度 の違いは考えられない，一方，超音波を用いて，三波川結晶片岩の弾性波速度の異方性が，例 えば [飯田・他 (1964), 小島 (1965)] によつて求められ, 軸方向の速度には大きな差がある. 三波川帯に大体平行している P 2 抢よびこれを切つている P 3 の走時を検討すると，異方性 


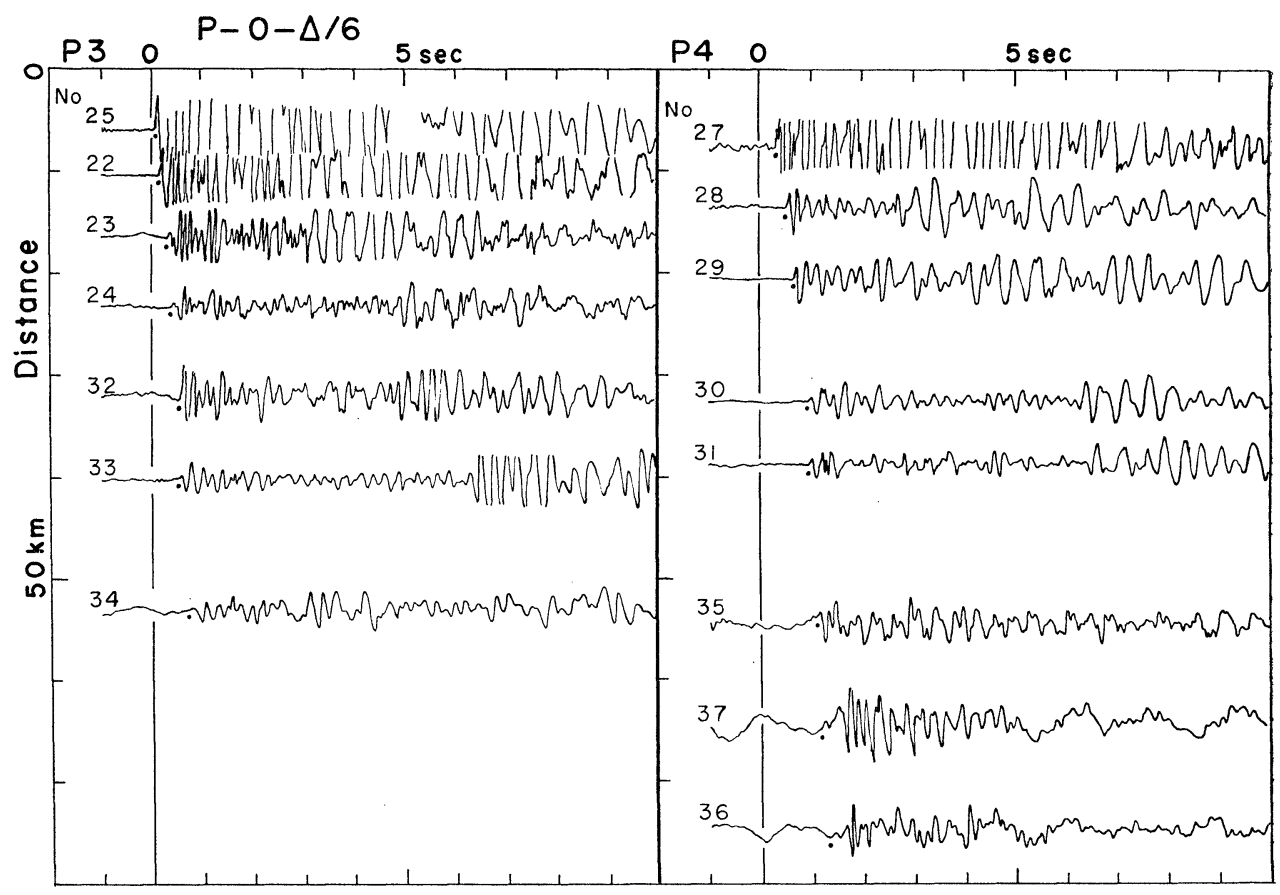

Fig. 5 b. Same as Fig. 5 a except for profiles P 3 and P 4 .

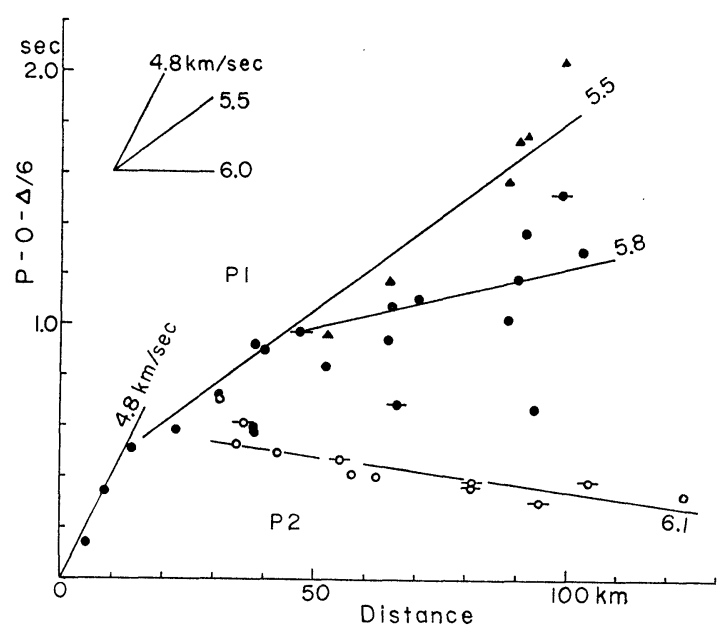

Fig. 6a. Reduced travel time curves with height correction for profiles P 1 (solid circles) and P 2 (open circles).

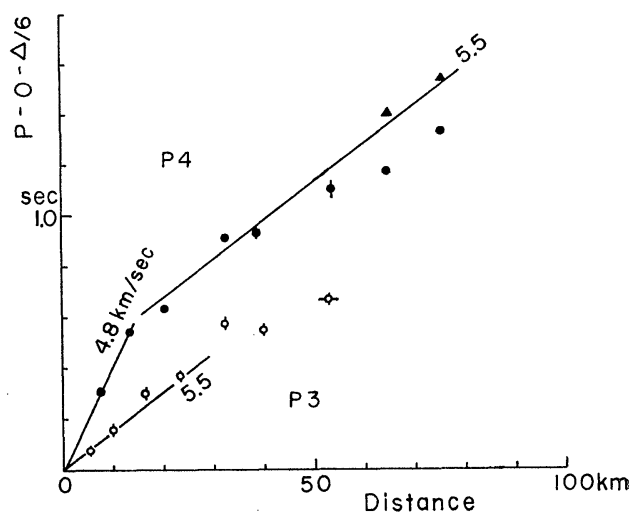

Fig. 6 b. Same as Fig. 6 a except for profiles $\mathrm{P} 4$ and $\mathrm{P} 3$.

は今回の観測結果を左右するほど大きいとは考えられない。このため，各測線の走時が変化す るのは層の傾斜に起因しているとして構造を求めた。この場合傾斜面は平面と考えた。 
構造を求めるために，発破点下の厚さを $0.1 \mathrm{~km}$ きざみで与光，各点への走時から傾斜角と 層の厚さを計算し，最小二乗法で近似面の傾斜角と発破点下の厚さを求め，この計算結果と与 えた厚さが一致するものを解とするといら方法を用いた。

第 I 層の構造の計算結果は観測点の組み合わせによつて異なるが，あまり大きくは变化しな い. 測線 P 2 と P 3 の方向では走時から判断して第 I 層はほとんど存在しないので除き， P 1 と P 4 の 15 点で計算すると，発破点下の厚さが $0.9 \mathrm{~km}$ ，等厚線の向さ（発破点下と同じ厚 さの点を結んだ線の方向）は $\mathrm{E} 23^{\circ} \mathrm{N}$, 第 I 層と第 II 層の境界面の傾斜角は 3.2 度(南下がり を正とする）である．Fig. 7 の（A）に求められた傾斜面と各点下の厚さを示し，その差は $\pm 1 \mathrm{~km}$ 内に収まつている，P4 の方向 (同図半黒丸) では多少異なるが観測点が少ないのでよ く分らない.

第 II 層の構造は，三波川帯では第 II 層を表層とし，それより南側では第 I 層の傾斜を考慮 して求められた. 測線 P 1 と P 2 の方向に分けて構造を求めると, P 1 の 11 点からは, 発 破点での第II層の下部までの厚さが $5.3 \mathrm{~km}$, 等厚線の向きが $\mathrm{E} 21^{\circ} \mathrm{N}$, 傾斜角が 12.8 度と求 まり，P2 の 10 点からは各々 $4.4 \mathrm{~km}, \mathrm{E} 25^{\circ} \mathrm{N}, 6.5$ 度となる。この場合もデータの組み合 わせによつて構造が変化し，P1 亿 4 を加えると傾斜角および等厚線の向さは共に大きくな る.ゆえに御荷錐構造線以南では，第 II 層の下部が東側に比べて西側でうすく，厚さを約

(A)

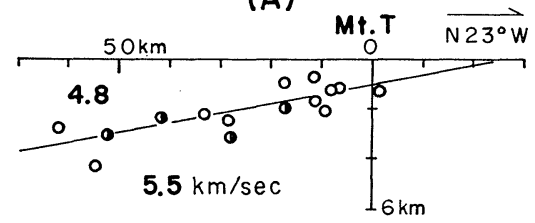

$\begin{array}{lll}\text { (B) } \overrightarrow{\mathrm{N} 21^{\circ} \mathrm{W}} & \text { (C) } \overline{\mathrm{N} 25^{\circ} \mathrm{W}}\end{array}$

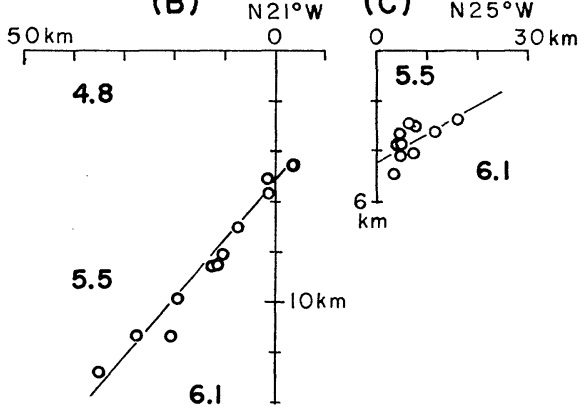

Fig. 7. Two interfaces in the upper crust calculated by the least square method, which are shown by solid lines.
$3.5 \mathrm{~km}$ 小さくすれば走時を説明でき る. P 1 と P 2 の場合の傾斜面と各点 下の厚さを Fig. 7 の (B) と (C) に 示し，傾斜面で近似できる事が分る. 両図から分るように各構造線を境とす る厚さの gap は, 今回の結果からは 明らかには認められない。

\section{§4. 検討}

いずれの測線についても逆測線がな いため，各速度は，観測点の平面的な 拡がりによるデータに基づいて推定さ れた訳であるが，第 I 層の $4.8 \mathrm{~km} / \mathrm{sec}$ を除いてはこれまでに爆破地震動観測 によつて求められている值と大差はな 
い. 第 I 層の速度は, 京都周辺で黒磯 (1972) が求めた速度 $4.6 \mathrm{~km} / \mathrm{sec}$ より幾分大きく, 地質帯表層部特有の招拉よその速度を示していると思われる．第 II 層と第 III 層の速度 5.5 , $6.1 \mathrm{~km} / \mathrm{sec}$ は, 外山爆破に基づいて青木・村松が求めた速度抢よび坂出沖爆破により伊神・他 (1975), HASHIZUME (1977) が求めた速度と矛盾しない.

前節で得られた結果の模式図を Fig. 8 a に，同図中の AA' で切つた断面図を Fig. 8 b に 示す．前図から，第 I 層㧍よび第监の等厚線の向さは，四国島弧あるいは御荷鉾構造線の方 向とほぼ平行している。しかし四国全域にわたつて一つの傾斜面では近似できない. 後図から， 第 I 層は御荷鉾構造線以南に存在し，南に向つて緩やかに厚くなる．第 II 層の下部面までの深 さは，三波川帯では南下がりにやや大さく御荷鉾付近で約 $4 \mathrm{~km}$ となり，これより南ではかな りの角度で深くなり, 四万十帯では $8 \sim 12 \mathrm{~km}$ と非常に大きくなる. 三波川帯の南縁の石原拉 よび四万十帯の馬路の二つの常時観測点で観測される一番短い $\mathrm{P} \sim \mathrm{S}$ 時間は，それぞれ約 0.7, 1.4 秒であり, これらは観測点下の地殼構造を反映しているものと思われる.地殼中の大部分 の地震は $6.0 \mathrm{~km} / \mathrm{sec}$ 層に発生すると言われ [例觉ば尾池(1975)], Fig. 1 飞示した浅い地震の グループの南下がりの傾斜（傾斜角約 15 度）が第 II 層と第 III 層の境界面を表わしていると

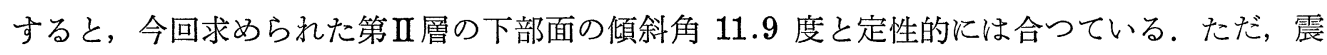
源分布は水平層構造に基づいて求められたものであり, 傾斜構造を取り入れると変化するかる 知れない。

発破点の位置や測線の方向は今回のものと異なつているが，これまでに求められている構造 と比較してみょう。市川は三波川帯大歩危背斜構造の地震探查の結果, 表層と次層の速度が $4.8 \sim 5.0$ と $6.0 \mathrm{~km} / \mathrm{sec}$, 表層の厚さが北部では約 $1.5 \mathrm{~km}$, 南部では約 $2.2 \mathrm{~km}$ と求めてお り，南下がりの構造とみれば今回の傾斜方向と矛盾しないが，層の厚さではかなりの差がある. これは測線の方向や長さの相違に起因しているのかも知れない，高知県の外山から淡路島の方 向に測線を設けた爆破地震動研究グループ(1974) の観測結果に基づき, 青木・村松は四国北東 部の granitic layer の深さが平均 $2 \mathrm{~km}$ 程度であつて南部にむかつて浅くなつている構造を求 めているが，今回の構造とはかなり異なつている。いずれにしても三波川帯では $6.1 \mathrm{~km} / \mathrm{sec}$ 層がかなり上部まで上がつている事は確かなようである。最近では爆破地震動研究 グループ （1978）によつて四国地域の地殼構造が明らかにされつつある。一方, 土佐湾, 四国沖の海底 地壳構造が DEN et al. (1968) 特よび YoSHII et al. (1973)により求められているが, 測線 がかなり南であり, 海底地殼構造の複雑さもあつて, 今回の構造と直接には結びつかない.

MATSUDA et al. (1967)は新第三紀以来の隆起・沈降図を表わし, これによると三波川帯付 近を中心にして隆起しいる.三波川帯のすぐ北側の構造は不明であるが（ずつと北の中国地方 


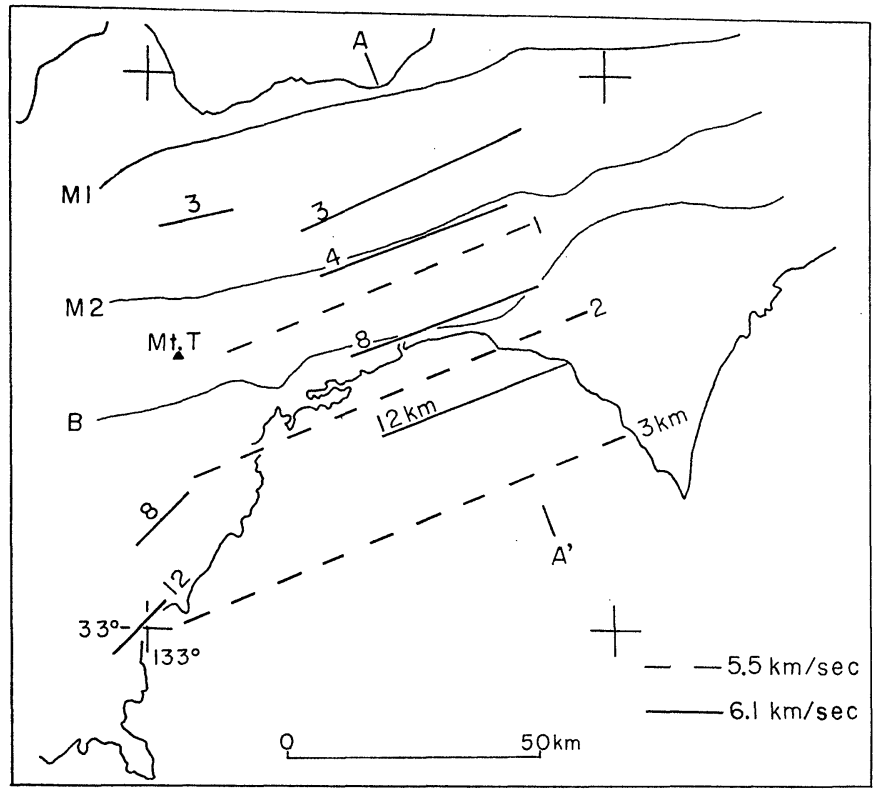

Fig. 8a. Map showing depths of the second and third layers with velocities of 5.5 and $6.1 \mathrm{~km} / \mathrm{sec}$, respectively.

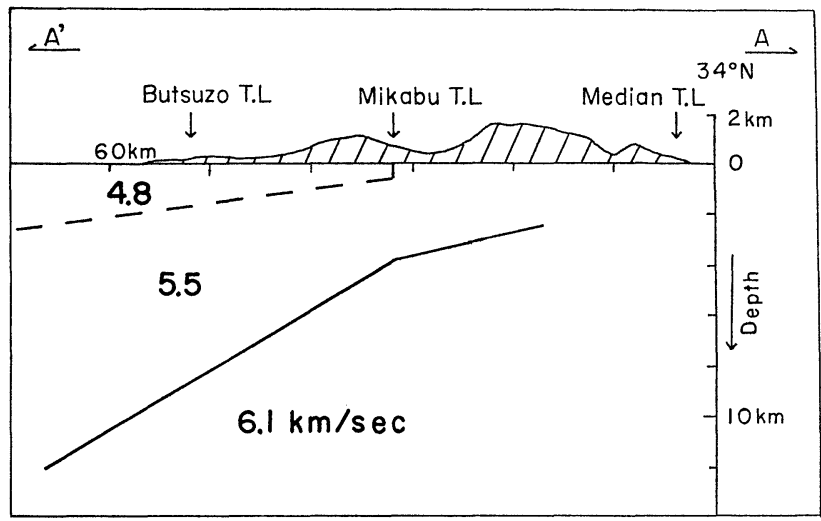

Fig. 8 b. Schematic profile in a vertical section along $A-A^{\prime}$ shown in Fig. 8 a.

北部の $5.5 \mathrm{~km} / \mathrm{sec}$ 層の厚さは YosHII et al. (1974) によれば $4.26 \mathrm{~km}$ ), 市川と青木・村松 の研究，今回得られた地殼上層部の傾斜構造および震源の深さ分布を考光併せた場合，三波川 帯付近では少なくとも $6.1 \mathrm{~km} / \mathrm{sec}$ 層の上面までが，周囲に対して隆起しているよらな構造で あると解釈できる，震源の深さ分布から考えて，構造の変化が下部面にまでおよんでいるよう であるが，この問題は今後の研究課題である. 


\section{§5. ま と め}

片測線ではあるが 4 方向に測線を設け，多数の観測点で採石発破の波を観測する事により， 四国内特に中央部の地殼上部には南下がりの傾斜構造が存在し, 地域的にも差のある事が分つ た．浅い地震の深さ分布に見られる南下がりの震源の分布は，今回求められた $6.1 \mathrm{~km} / \mathrm{sec}$ 層 の上部面の傾斜構造と定性的には合つている.

1）表層部には $4.8 \mathrm{~km} / \mathrm{sec}$ とかなり小さな速度の層が存在し，これより下部層の速度 5.5 , $6.1 \mathrm{~km} / \mathrm{sec}$ はこれまでによく知られている值と大差ない.

2)等厚線の向きは $4.8 \mathrm{~km} / \mathrm{sec}$ 層, $5.5 \mathrm{~km} / \mathrm{sec}$ 層共に $\mathrm{E} 21 \sim 25^{\circ} \mathrm{N}$ を示し, 四国の島弧 の軸あるいは構造線の方向とほぼ平行である。

3) $4.8 \mathrm{~km} / \mathrm{sec}$ 層は御荷鉾構造線以南に存在して南に向つて厚くなる $(0.6 \sim 3 \mathrm{~km})$ ．地表 から $5.5 \mathrm{~km} / \mathrm{sec}$ 層の下部面までの深さは，三波川帯中部から南にやや大きくなり (2.5〜 $4 \mathrm{~km})$ ，秩父・四万十帯ではかなりの角度で深くなる $(4 \sim 12 \mathrm{~km})$. 三波川帯の 地殼上層部は 南側に比べてかなりうすく，過去の地質活動を反映しているものと思われる.

今回求められた結果を基にして地殼下部の構造を求め，地震活動と構造との関連性を明らか にしてゆきたい.

\section{謝辞}

発破の観測および解析研究を進めるに際し, 終始御指導頂きました岡野健之助教授に厚く御 礼申し上げます．観測に際して御協力下さつた当観測所の川谷和夫技官に感謝の意を表します。 また，発破点での観測や図面入手等に種々御便宜を頂きました鳥形山山頂事務所の方々に御礼 申し上げます。

なお，データ解析には高知大学計算センターを利用しました。謝意を表します。

\section{文献}

青木治三・村松有栄, 1974, 御母衣一外山測線に沿 万近畿・四国地方の地殼構造, 地震, $2,27,104-109$. 爆破地震動研究グループ，1974，四国外山爆破による地震動の観測，地震，2，27，95-103.

爆破地震動研究グループ, 1978, 鳥形山・家島爆破地震動観測に上る四国地域の地殼構造, 地震学会講演予 稿集, No. 1, 172.

- Den, N., S. Murauchi, H. Hotta, T. Asanuma, and K. Hagiwara, 1968, A Seismic Refraction Exploration of Tosa Deep-Sea Terrace off Sikoku, J. Phys. Earth, 16, 7-10.

Hashizume, M., 1977, A Seismic Wave Velocity along the Sanbagawa Metamorphic Belt in Shikoku Area, Southwestern Japan, J. Phys. Earth, 25, 91-101.

市川金徳，1968，四国大歩危周辺地震探査について，地調月報，19，385-395.

飯田泛事・熊沢峰夫・鈴木一㤵，1964，結晶片岩の弾性波速度と波動減衰の異方性，地震，2，17，166167. 
伊神 輝・伊藤 潔・佐々木嘉三・浅野周三, 1975,1975 年 3 月坂出沖爆破, 地震学会講演予稿集, No. $2,21$.

小島丈児，1965，片状岩類の物理的性質と岩石構造の関係について，広大地研報，No. 14，1-12.

黒磯章夫, 1972, 京都周辺の地下構造 ( I ), 地震学会講演子稿集, No. $2,98$.

Matsuda, T., K. Nakamura and A. Sugimura, 1967, Late Cenozoic Orogeny in Japan, Tectnophysics, 4, 349-366.

尾池和夫, 1975, 鳥取微小地震観測所の震源表について, 地震, 2, 28, 331-346.

岡野健之助・木村昌三・許斐 直, 1977, 四国地方の地震活動，地震予知連絡会会報，18，117-119.

大久保雅弘・藤田至則編, 1966, 地学ハンドブック, 築地書館, 226.

Yoshil, T., W. J. Ludwig, N. Den, S. Murauchi, M. Ewing, H. Hotta, P. Buhl, T. Asanuma, and N. SAKAJIRI, 1973, Structure of Southwest Japan Margin off Shikoku, J. Geophys. Res., 78, 2517-2525.

Yoshil, T., Y. Sasaki, T. Tada, H. Okada, S. Asano, I. Muramatu, M. Hashizume, and T. Moriya, 1974, The Third Kurayosi Explosion and the Crustal Structure in the Western Part of Japan, J. Phys. Earth, 22, 109-121. 